\title{
Structural Constraints to African Continental Free Trade Area: Prospects, Issues and Policy Options
}

\author{
Ogujiuba Kanayo ${ }^{1,2}$ \\ ${ }^{1}$ School of Development Studies, University of Mpumalanga, South Africa \\ ${ }^{2}$ Senior Research Fellow, University of the Western Cape, South Africa \\ Correspondence: Ogujiuba Kanayo, School of Development Studies, Faculty of Economics, Development and \\ Business Sciences, University of Mpumalanga, South Africa. E-mail: Kanayo.Ogujiuba@ump.ac.za
}

Received: June 6, 2021

Accepted: August 4, 2021

Online Published: September 7, 2021

doi:10.5430/rwe.v12n4p54

URL: https://doi.org/10.5430/rwe.v12n4p54

\begin{abstract}
The foremost intents of the African Continental Free Trade Area (AfCFTA) predicates on the integration of the African continent into mobile flows of trade and investment. This framework is structured to boost industrial development within the continent. However, statistics show an abysmal trade performance for Africa in comparism to the rest of the world. In contrast, projections indicate that the benefactors of the AfCFTA framework would be SMEs in the short term, which account for more than $75 \%$ of the continent's businesses. Notwithstanding Africa's resolve to disassemble trade restrictions, barricades to intra-African trade have persisted. Conversely, the scheduling of AfCFTA stands in sharp contrast with an international perspective framed by a tenacious increase in trade-restrictive processes. The pertinent question remains, can the objectives of AfCFTA increase Intra African Trade, given the persistent structural barriers in the continent. Using a desktop approach and secondary data, this article examines contemporary issues, which encumber trade within and amongst the regional blocks. From our examination, the foremost obstacle to AfCFTA have a fundamental political focus rather than an economic dimension. Accomplishing AfCFTA objectives would entail a strong political will and efforts by political leaders in Africa; if the barriers are effectively fixed, AfCFTA could attain a welfare improvement projected at over 16 billion dollars.
\end{abstract}

Keywords: AfCFTA, barriers, economic, tariffs, trade

JEL Codes: F14, F43, O24

\section{Introduction}

The economy of the globe today is vibrant and mutually dependent. International trade and investment flows have a scale never seen before. However, in comparative terms, the global economy is not as intertwined as it was at the end of the 19th century. Integration permits countries that are linked into mobile trade and investment to leverage external resources for domestic growth. The question that each country face is how to acquire external resources on a sustainable basis, in a way that matches domestic development strategies. However, Stiglitz posited aftermath of the 1997-1998 Asian financial crisis, opening to these flows, precisely on the financial front, is fraught with risks, and thus needs cautious management (Stiglitz 2002). Nonetheless, effective integration entails strong states being capable of supporting markets amongst its members that are susceptible to failure and of mobilizing and directing resources to areas where required. Regrettably, this is a prerequisite fundamentally absent in the African context, where governance problems and lack of competence amongst other issues thrive. However, been over-exposed to this situation, the African continent tends to hang on the margins. Nowhere is this more obvious than in trade and foreign direct investments (FDI) flows. The proportion of global trade contributed by Africa is little. Additionally, the continent has largely been incorporated into the world economy as an exporter of commodities, primarily to the European Union (EU), and an importer of capital equipment, manufactures and services. Certainly, this summative representation lacks gradation. For instance, Kenya with all its political glitches, nonetheless, has emerged as a regional hub for East Africa that exports substantial quantities of manufactures increasingly to its neighbours. Another example is South Africa, another country that does not fit the above profile, but the situation holds true for much of Sub-Saharan Africa. 
Africa contributes to a very small portion of global FDI flows (2-3\%) of the world total (UNCTAD 2005). Additionally, the topmost ten countries in Africa that obtain such investment regularly account for more than three-quarters of FDI into the continent (UNCTAD 2005). This concentration also applies to source countries. For instance, 70 per cent of FDI inflows between 1980-2000 came from only three (United States, France and United Kingdom)). The structure is very different from East Asia, especially China, which gains most of the world's investment. FDI fixated towards the latter is both efficiency seeking and market seeking, and the source countries are many and broadly spread. FDI inflows into Africa, on the other hand, are mostly resource seeking, which underlines the commodity-dependent export characteristics of countries on the receiving end (UNCTAD 2005). The World Investment Report 2005 published by the United Nations Conference on Trade and Development (UNCTAD) posits that this gives FDI into Africa a manifest character. Investment is mostly capital-intensive and greenfield in nature; is not strongly connected to the domestic economy; and does not reinvest profits. The authors argue that this holds a added danger: countries become susceptible to influential multinational corporation interests that focused on extraction of resources, probably at expense cost for domestic manufacturing interests. This, inclines to undermining domestic diversification policies. There is also, the possibility that large-scale profit repatriation could deteriorate the balance of payments for the countries concerned (UNCTAD 2005).

However, African leaders have since acknowledged the significance of regional integration as a proposition for economic growth within the continent. As such, the New Partnership for Africa's Development (NEPAD) as well as the regional economic communities (RECs) inventiveness were executed within the African continent to improve the level of integration progress. In addition, the (COMESA-EAC-SADC) tripartite Free Trade Agreement (FTA) has made some level of effort to consolidate this integration, which is a great testimony, towards Africa's desire and progress in regional integration (AfDB 2011). Nevertheless, improving intra-African trade entails both the admittance and execution of comprehensible and well-ordered trade policies at all levels; continental, region-wide and national levels. Although trade liberalization within regions institutes an important component towards integration for most of Africa's RECs, yet executing suitable trade procedures seldom harmonizes this urgency, which is essential for the recognition of market mixing. Thus, considerable dissimilarities still occur in trade rubrics especially inside and amidst the RECs. Africa is faced with several obstacles, which goes past the structural limitations, such as low levels of incomes and investment, absence of resources and production complementarities amongst many African states. Furthermore, there are countless infrastructural connected, and policy prompted inhibitions to intra-African trade. Fundamentally, trade within Africa is still low (see table 1), as regional trade agreements (RTAs) which were approved by member-states have not been completely implemented. Further, non-coastal African nations experience enormous trade challenges and extra intimidating complications especially about expanding their own share of trade transactions within the continent (AfDB 2011). The rather low level of trade within Africa and portion of Africa in international trade is mainly accredited to the insufficiency of industrial (Note 1) capacity, within active sectors of international trade. Henceforth, the contribution and immersion of many states in Africa within the global economy is less than optimal.

Table 1. Intra-regional export, selected years (\% of total exports)

\begin{tabular}{lllllll}
\hline Region & 1995 & 2000 & 2005 & $\begin{array}{l}\text { Average } \\
2006-2008\end{array}$ & 2010 & 2015 \\
\hline Africa & 17.87 & 9.46 & 9.57 & 9.64 & 10.0 & 10.64 \\
\hline North Africa & 4.85 & 2.62 & 2.78 & 3.02 & 2.85 & 3.12 \\
\hline Sub-Saharan Africa & 22.74 & 12.61 & 12.48 & 12.33 & 14.34 & 16.5 \\
\hline Developing Asia & 42.16 & 41.69 & 46.21 & 47.93 & 49.38 & 52.85 \\
\hline Developing America & 19.67 & 17.71 & 18.51 & 20.00 & 20.1 & 21.2 \\
\hline Developed America & 35.87 & 39.56 & 40.64 & 36.72 & 44.35 & 47.84 \\
\hline Developed Europe & 54.84 & 44.76 & 45.54 & 54.67 & 48.75 & 53.2 \\
\hline
\end{tabular}

Source: UNCTAD. 1995 to 2008

Author's Calculation for 2010 and 2015 from various sources (AfDB 2011 and AfDB 2018) 
Besides, furthering the enhancement of the continents share (Africa) within global trade and Intra-African Trade (IAT) necessitates the increase of industrial capacity and economic modification. For example, other regions sophisticated experience which has prospered them in attaining higher levels of intra-regional trade and substantial global trade shares displays significant industrial and competitive capacity within active segments of international trade (industrial and services). Though global trade within Africa is low, yet trade expansion remains very strong for semi-manufacturers and industrial goods, whose intra-trade shares increased by $9 \%$ and $14 \%$ respectively; from $16 \%$ (2000) to $25 \%$ (2010) and $12 \%$ (2000) to $26 \%$ (2010) (Note 2). Similarly, eight years later (2018) these figures further increased by $20 \%$ from 2010 to $46 \%$ and by $22 \%$ from 2010 to $48 \%$. (ITC 2012)

Total trade from Africa to other continents aggregated to about 760 billion dollars in existing prices between 2015-2017, compared to Oceania, Europe, America and Asia that had respectively $\$ 481, \$ 4109, \$ 5140$ and $\$ 6801$ (billion). These figures show how dismal, the performance from Africa. Further, Africa's own portion of exports to other parts of the world is between 80\% (2000) to 90\% (2017) (Note 3) (AfDB 2018). The unpredictability of both economic progress related to economic surprises and earnings in exports, for economies largely relying on exports, makes them defenceless. Nevertheless, exports from within Africa on average is approximately $16.6 \%$ of total 2017 exports, however Europe, Asia, America and Oceania had 68\%, 59\%, 55\% and 7\% correspondingly. In contrast, African trade being computed as the average of Africa's (within) exportation and importation, was approximated at $2 \%$ between 2015-2017, while numbers from America, Oceania, Asia and Europe were much higher and correspondingly 47\%, 7\%, 61\% and 67\% (AfDB 2018). Nevertheless, the intra-African exports from highest to lowest include Algeria (5.5\%), Liberia (5.1\%), Guinea Bissau (4.7\%), Libya (4.5\%), Libya (4.5\%), Angola (3.9\%), Cabo Verde (3.6\%), Equatorial Guinea (3.5\%), Eritrea (2.3\%), Guinea (1.6\%) and Chad (0.2\%). Matched with all other counties, Sub-Saharan Africa has both the highest cost of exportation and importation while excluding the Caribbean and Latin America due to boundary acquiescence in the regions, and South Asia, because of documented compliance.

The reduction of tariffs and non-tariff barriers (NTB) and application of regional trade agreements (RTAs) to trade has been extremely sluggish. In addition, most nations have drawn extensive lists of delicate goods as exclusions to intra-RTA trade liberalism. In RTAs where development combined with integration was faster, trade flows were not increased spontaneously, such as CEMAC and COMESA. Consequently, the intra-African regional trade flows have been sluggish in contrast to other regions, mostly developing regions (AfDB 2011).

Table 2. Intra-regional and intra-Africa export by RECs (\% of total exports)

\begin{tabular}{|c|c|c|c|c|c|c|c|}
\hline & 2000 & 2003 & 2005 & 2007 & 2010 & $2014^{x}$ & $2017^{x}$ \\
\hline Intra-EAC exports & 22.5 & 21.3 & 18.1 & 17.7 & 20.1 & 22.3 & 23.1 \\
\hline EAC exports to Africa & 32.1 & 32.3 & 28.8 & 31.0 & 32.3 & 32.8 & 34 \\
\hline Intra-UMA exports & 2.4 & 2.6 & 2.1 & 2.1 & 2.4 & 3.0 & 3.7 \\
\hline UMA exports to Africa & 2.5 & 2.5 & 2.2 & 3.3 & 2.9 & 3.2 & 3.8 \\
\hline Intra-SADC exports & 8.8 & 10.0 & 8.3 & 8.5 & 8.6 & 8.4 & 8.7 \\
\hline SADC exports to Africa & 11.5 & 13.1 & 11.5 & 11.2 & 12 & 12.3 & 11.8 \\
\hline Intra-WAEMU exports & 10.9 & 11.4 & 11.1 & 12.4 & & 13.6 & 14.1 \\
\hline WAEMU exports to & 24.9 & 23.0 & 25.7 & 30.7 & & 35.3 & 37.3 \\
\hline \multicolumn{8}{|l|}{ Africa } \\
\hline Intra-CEMAC exports & 1.0 & 1.2 & 0.7 & 1.1 & & 1.8 & 2 \\
\hline CEMAC exports to & 3.6 & 3.5 & 3.0 & 3.1 & & 3.8 & 4 \\
\hline
\end{tabular}

Africa

Note: East African Community (EAC), UMA (UMA), South African Development Community (SADC), WAEMU (WAEMU), CEMAC (CEMAC)

${ }^{\mathrm{x}}$ Source: Author's Computation from ECA; AfDB and AUG several reports

Regarding the fragile trade performance within the African region, there are several whys and wherefores. Regional integration in the continent up to now has been more fixed on the eradication of trade complications and not as much 
of on upgrading of the productive proficiencies, which are essential for trade. Although, trade barrier-eradication is imperious, it will not have a desirable influence; especially when it's not supplemented with policy activities that would raise supply capabilities (Note 4). Contrary to this context, worldwide, the African continent still upholds the lowest developed industrial level; it takes up to $<1 \%$ of the manufacturing value added worldwide. Consequently, only a small number of African states have thrived in evolving a considerable and lively industrial sector whose GDP involvement is above $20 \%$. Accordingly, in order to meet the demand of factory-made goods (for the reason that they lack the productive capacities and competitiveness), the African continent seriously depends on the outside world (UNCTAD 2013). As per the number of countries involved (with a collective GDP that is worth over two trillion dollars a year) and the concerned population of about 1.2 billion persons, the AfCFTA epitomizes the foremost free trade agreement ever-since the foundation of the World Trade Organization. Likewise, imperative is the scheduling of the pact, as it stands in sharp difference with an international setting marked by a tenacious and substantial increase in trade-restrictive practices, as well as by a rising opposition to the expansion of region-wide integration systems.

Notwithstanding the lengthy African-history of region-wide integration within the continent, the level of Intra African Trade (IAT) is still little and in contrast with other unindustrialized nations. Intra African exportation of the region's total exports is low (9.6\%), whereas Latin America and Asia has 20\% and 48\% respectively. This percentage is considerably higher for sub-Saharan Africa (SSA), which is about $12 \%$ more than the North African portion estimated at 3\% that has methodically presented very low stages of intra-regional trade (AfDB 2011). A major impediment to IAT are the NTBs, in addition to the sub-structural, policy and bureaucratic restraints, which produce trade blocks. Consequently, this has led to burdensome documentation necessities, multifaceted authorization procedure and erratic trade policies, all contributing to high intra-Africa trade costs (Viljoen 2019). According to the United Nations Economic Commission for Africa (UNECA), the effective implementation of the AfCFTA pact could rise intra-African trade by over 50\%, compared to the levels of 2010, by 2022, thus dipping the gap with intraregional trade quotas currently portraying North America (54\%), Europe (67\%) and Asia (51\%). In the short term, the main benefactors of the AfCFTA would be small and medium sized enterprises that account for $70 \%$ of the continent's companies. Nonetheless, from medium to long term, it is expected that the gains will extend to all African citizens, who will achieve a wellbeing gain projected at 16.1 billion dollars, particularly favouring women (Note 5) and young persons, who could profit from new job openings. The intra-African economic and commercial evolution would mostly influence the industrial and manufacturing sectors, thus indicating AfCFTA's budding role in guiding the structural transformation of African countries.

Notwithstanding Africa's determination to undo trade barriers in order to create a common market within the context of regional and sub-regional treaties, impediments to intra-African trade persist. Over the past decade and on average, only about $10-12$ percent of African trade is within African countries, while, 40 percent of North American trade is with other North American countries, and 63 percent of trade by countries in Western Europe is with other Western European nations. Moreover, while the rest of the world's economy grew at a yearly rate of about 2 percent from 1960 to 2002, growth path in Africa has been bleak. From 1974 through the mid-1990s, growth was negative, with a negative of 1.5 percent in 1990-4. As a result, hundreds of millions of African populations have become poor: one-half of the African continent lives below the poverty mark. In sub-Saharan Africa, per capita GDP is now less than what it was in 1974, having dropped over 11 percent. In 1970, one in ten poor citizens in the world lived in Africa; by 2000, the number was closer to one in two. That trend translated into about 360 million poor Africans in 2000 , compared to 140 million in 1975 . As of 2015 , the 2000 figures have doubled.

Despite the long history of regional integration on the continent, the level of intra-African trade remains low in comparison with other developing regions. Intra-African exports represent 9.6 percent of the region's total exports, compared to 20 percent for Latin America and 48 percent for developing Asia. This proportion is substantially higher for sub-Saharan Africa (around 12 percent) than for North Africa (around 3 percent), which has systematically featured very low levels of intra-regional trade. There is no doubt, that trade is the key to enduring, sustainable economic growth in sub-Saharan Africa, and vital to improving lives and livelihoods. At the moment, Africa has about 2 percent of all world trade, which is inadequate when considering the huge resources in the region not to mention all the agricultural products and to think that Africa still only has 2 percent of world trade is really ludicrous. Nevertheless, the power of trade is that if the Africans were able to grow their portion of world trade from 2 to 3 percent, the 1 percentage upsurge would generate about $\$ 70$ billion of additional income annually for Africa, or about three times the total aid Africa receives from the entire world. Many countries globally, do not have a quarter of Africa's natural resources. Furthermore, Africa's share of the U.S. import apparel market is less than 2 percent. By contrast, Bangladesh exports to the United States three to five times the amount of apparel that is exported to the 
United States by all sub-Saharan African countries. This indicates huge potential for Africa but somehow that is not being advanced as result of structural challenges in its regional trade arrangements. Beyond the structural constraints, such as absence of resource and production complementarities between many African nations and low point levels of incomes and investment, there are several infrastructure related and policy-induced obstacles to intra-African trade.

On the other hand, Africa is home to more landlocked countries than any other continent. Fifteen African countries, representing about one-third of Africa's population, are landlocked. These countries face tremendous challenges to join the regional and global markets. Africa has more nations with low population concentrations than other developing regions. Nineteen African countries have less than 5 million people; only one country (Nigeria) has a population surpassing 150 million. Additionally, income levels are very low across nations, regardless of their size. As a result, the continent comprises mainly nations that have insignificant domestic markets with low purchasing power. Most African countries are far from major markets of Europe and the USA. They are also far from busy shipping routes to these markets.

It is then important for African countries to address the barriers to regional trade and integration. It is critical to interrogate the reasons behind the reality that Africa has only achieved $15 \%$ of intraregional trade and $3 \%$ of global trade (Afreximbank, 2018). Even that performance percentage is driven by just four countries: South Africa, Namibia, Zambia and Nigeria - in that order - which does not compare favourably with intracontinental trade in the European Union (EU) (67\%), Asia (58\%), North America (48\%) and even Latin America (20\%) (PricewaterhouseCoopers, 2019).

\section{Contemporary Issues: Intra-African Trade}

There is a substantial body of literature on continental free trade agreements and socio-economic growth. Hosny (2013) contends that regional integration is characterised by improved competition, investment flows, economies of scale, technology transfer and enhanced productivity.7 According to Marinov, the effects of regional economic integration incorporate increased investment, expenditure, sustainably increased demands, the consolidation of production and increased specialisation, improvement of the organisation and management of production and production technology, justification of territorial distribution and utilisation of resources, increased production efficiency, and the improvement of economic growth (Marinov, 2014). Wandrei opines that trade agreements eventually lead to trade gains for participating countries (Wandrei, 2018).

Examining the implications of the AfCFTA for individual states, Jibrilla (2018) argues that Nigeria's earlier refusal to sign the AfCFTA was misguided. He contends that Nigeria stands to benefit the most from the agreement if the country improves its infrastructure, develops human capital, empowers youth and women, develops the agricultural sector, attracts quality foreign direct investment, encourages value addition, designs and implements policies that will allow access to finance by investors, and manages the security situation better (Jibrilla 2018). However, Ubi (2018) supports Nigeria's initial refusal to sign the agreement, arguing that the AfCFTA was likely to undermine local manufacturers and entrepreneurs or lead to Nigeria becoming a dumping ground for finished goods. Ubi further argues that Africa's development cannot be attained by free trade agreements, because past and current trade agreements involving African nations, particularly Nigeria, have not had any significant impact on the Nigerian economy (Ubi, 2018).11 He further claims that most African countries are not mature enough for free trade, because of the lack of industrialisation. Ubi also states that the manufacturing sector in sub-Saharan Africa has not shown any growth since the 1970s, as the value-added goods percentage of the gross domestic product (GDP) has stagnated at $10 \%$ (Ubi, 2018).

Intra-regional trade (IRT) attracts regional foreign direct investment (FDI) and nurtures the negotiation capacity of contributing countries. Most importantly, IRT does advance communal welfare by permitting them to attain goods and services from the most inexpensive source (ECA 2015). On the other hand, profits (Note 6) do rely on the level of integration and corresponding internal policies. Nonetheless, the low degree of trade within the African continent is all due to the absence of product diversification and trade hindrances. These structural chains are complicated by unsatisfactory infrastructure, both soft as well as hard substructure. Still, several features cause a reduction in firm-level production, increase the cost of production, and penetrates export affordability, which often causes trade-impediment within the borders of the African continent. Such features do consist of a lack of work-access to investment and trade investment, old-fashioned technology, non-worker training, unreliable and exorbitant values, as well as a non-advantageous macroeconomic setting, which results in the lack of exportation motivation and low levels of investment (UNCTAD 2013) and (Viljoen 209). For example, NTBs declines can surge economic progress and increase size of intra-African exports and imports, consequently, improving trade terms athwart the African continent (Alemayehu and Haile 2007). 


\subsection{Common Market for Eastern and Southern Africa (COMESA)}

Burundi, DRC, Egypt, Kenya, Madagascar, Mauritius, Rwanda, Sudan, Zimbabwe, Angola, Comoros Djibouti, Eritrea, Ethiopia, Malawi, Namibia, Seychelles, Swaziland, Uganda and Zambia make up the 20 member nations of COMESA. This market (COMESA) was launched with an outlook to accomplish maintainable development via progressive realization of integration, beginning with privileged trade area, then becoming a communal market, Moreover, the member's exports to their primary trading associates is coffee, which is a significant one. The factory-made products disseminated are textiles compared to other manufactured goods (Mushonga and Ikhide 2017). This reveals the non-corresponding features of the intra-COMESA trade, which is void of diversity. Relatively, advanced countries like Kenya and Egypt within the group have a solid manufacturing sector and are in a more improved position to promote exportation within COMESA. However, the less developed economies in the group are not able to discover important markets. These misaligned production counterparties does favour most developed members' nations as it elevates the apprehension over a possible polarization towards investment, to the bigger and more technologically diversified economies in the region. Even so, in COMESA, member states have been obliged to institute a customs union, eliminate all non-tariff barriers, and decide a collective external tariff and follow shared standards of custom processes. Amongst those commitments, FTA is established to enable regional integration via zero customs tariffs on goods transacted among the Member States. To this end, Member states made specific undertakings to institute a customs union. However, the optimum effects of the reforms are yet to be seen.

\subsubsection{Challenges of Trade in COMESA}

$>$ Overlapping memberships is an impediment to regional integration, because among other issues, it presents replication of efforts. Several economic zones are existing in the Southern and Eastern Africa region (COMESA, EAC, SADC, SACU, and IGAD) and most states are members of more than one such economic block. For example, Dem. Rep. of the Congo, which is a member to COMESA, is as well a member to ECCAS and SACU while other members of COMESA, Uganda and Kenya are likewise members of EAC. Negotiating resources and capacity are stretched thin across COMESA region leading to a structural challenge for the operationalization of AfCFTA.

$>$ Similar to other regional trade arrangements, COMESA region is characterized by acute economic disparities and inequalities. In such a scenario, some relatively better economies in the region are reaping more economic benefits (CUTS 2015), which creates hesitation among member countries. Moreover, most counties are concerned about aggressive rivalry from relatively industrialized members such as Kenya, Egypt and Mauritius. Hence, an integration scheme where countries are at different levels of development with disproportionate gain; leads to a negative impact on domestic economies of the less developed countries (Note 7).

$>$ There exists a very small amount of private sector contribution towards the discussion of integration ingenuities. However, non- public actors do participate in Africa's economy through certain duties, which are not considered of high integration-value (Alemayehu and Haile 2007). This facet of local integration process in COMESA has been identified as a main loophole. Further, the private sector is not yet authorized to take up any vibrant role in nationwide trade policy making or local integration (Hulse 2014).

$>$ Dismal infrastructure deprives COMESA, the ability to plan, implement and maintain adequate and robust trade networks. These infrastructure covers transport, information communications technology, energy and trans-boundary water. The COMESA regional infrastructure deficits come primarily from the lack of resources and capacity within the Member states.

\subsection{Economic Community of West African States ECOWAS}

In West Africa, there exists, two leading region-wide blocks namely, UEMOA (Union Économique et Monétaire Ouest-Africaine) and ECOWAS (the Economic Community of West African States). Member states for both have proposed to unify existing French-speaking nations of UEMOA with the five states speaking English and two others speaking Portuguese in the region (Hulse 2014), with the main aim of advancing monetary integration. Fifteen nations (Liberia, Guinea-Bissau, Mali, Guinea, Niger, Ghana, Nigeria, the Gambia, Senegal, Cape Verde, Burkina Faso, Côte d'Ivoire, Sierra Leone, Togo and Benin) make up the Economic Community of West African States (ECOWAS). In 2015, the ECOWAS achieved a GDP of 664 billion dollars and between the periods of $2000-2015$ realized $6.4 \%$ real GDP development rate.

The growth of ECOWAS growth is driven mainly by Nigeria - the biggest economy within the block. Nigeria in 2014 accounted for over 75\% of the collective GDP, with Ghana and Côte d'Ivoire contributing 5.3\% and 
approximately 5\% respectively. As well, discrepancies do exist regarding growth rates between member States in terms of income per capita, which fluctuated between 358 US dollars in Niger and 3,035 US dollars in Cape Verde. Nevertheless, ECOWAS's (Note 8) trade outline does not have a robust modification especially since the region largely exports a restricted quantity of raw materials and imports manufacturing goods and more food items increasingly. IRT in ECOWAS is trivial, comprising of staple food, and essentially informal. Still, most of the recorded statistics in trade do show that this area mostly depends on the exportation proceeds of a restricted amount of definite raw supplies like cotton, rubber petroleum and natural gas. Food importation is increasing thus causing a progressive detrimental food trade balance. Enhancing of IRT is important for maintaining development. This comes from the fact that it produces chances for economies of scale and allows the flow of food in abundance from high food to low food zones (Note 9).

Table 3. Main Products of Intra-ECOWAS trade

\begin{tabular}{llll}
\hline & Items & US\$ million & Share (per cent) \\
\hline 1. & Fuel oils, bitumen oils, resources, crude & 3140 & 31.3 \\
\hline 2. & Fuel oils or bituminous minerals > 70 \% oil & 1707 & 17.0 \\
\hline 3. & Lime, cement, fabrica. constr. mat. (excluding glass, clay) & 342 & 3.4 \\
\hline 4. & Tobacco, manufactured & 250 & 2.5 \\
\hline 5. & Edible products and preparations, n.e.s. & 242 & 2.4 \\
\hline 6. & Perfumery, cosmetics or toilet prepar. (excluding soaps) & 234 & 2.3 \\
\hline 7. & Fixed vegetable fats \& oils, crude, refined, fract. & 225 & 2.2 \\
\hline 8. & Articles, N.E.C., of plastics & 216 & 2.2 \\
\hline 9. & Electric current & 182 & 1.8 \\
\hline 10. & Footwear & 148 & 1.5 \\
\hline
\end{tabular}

Source: UNCTADstat; Merchandise trade matrix export figures are used.

Regarding ECOWAS trade, intra-group trade covers a restricted variety of goods like tobacco, fuels, ocean/stream navigating equipment and cement (Table 3 ). Petroleum goods in 2015 , solely comprised of $48.4 \%$ of intra-ECOWAS trade, likewise, there are other goods like cereals, roots and their derivatives, live cattle, tubers and vegetable oils, which are mostly casually traded and are henceforth poorly documented (ACTID 2012).

\subsubsection{Challenges of Trade in ECOWAS}

$>$ Complicated and long custom measures still remains the main impairment to trade within the region. Notwithstanding that promises has been made by member states to address the issue, there is no evidence of any action. In-addition, lack of political will by ECOWAS leaders poses a significant threat to AfCFTA: Some state members do not have the ability to keep obligations, which do necessitate robust political manoeuvrings. There are no penalties for non-adherence to stated protocols (World Bank 2015).

$>$ There exists a total knowledge-gap and a non-factual response mechanism on existing trade policies in UEMOA nor ECOWAS, nor an active disagreement and binding mechanism approvals. Another issue that has emerged is non-satisfactory information on trade and regional taxes. Officials are always not well informed about their responsibilities. This affects those involved in trade across the border, most of whom are uneducated and not familiar with trade procedures either (Yusuff 2014).

$>$ Several studies that point towards the widespread nature of corruption within region especially the incidence of crooked and dishonest duties, procedures and road nuisances. These blockades and borderline briberies have caused expensive and lengthy delays (OECD 2009); (Engel and Jouanjean. 2013) and World Bank 2015). Consequently, (Engel and Jouanjean. 2013) postulates that the numerous fees paid are comparatively trivial. Therefore, this makes it tough for different trader-groups, manufacturers and truck drivers in ECOWAS to demand a tax certificate. 


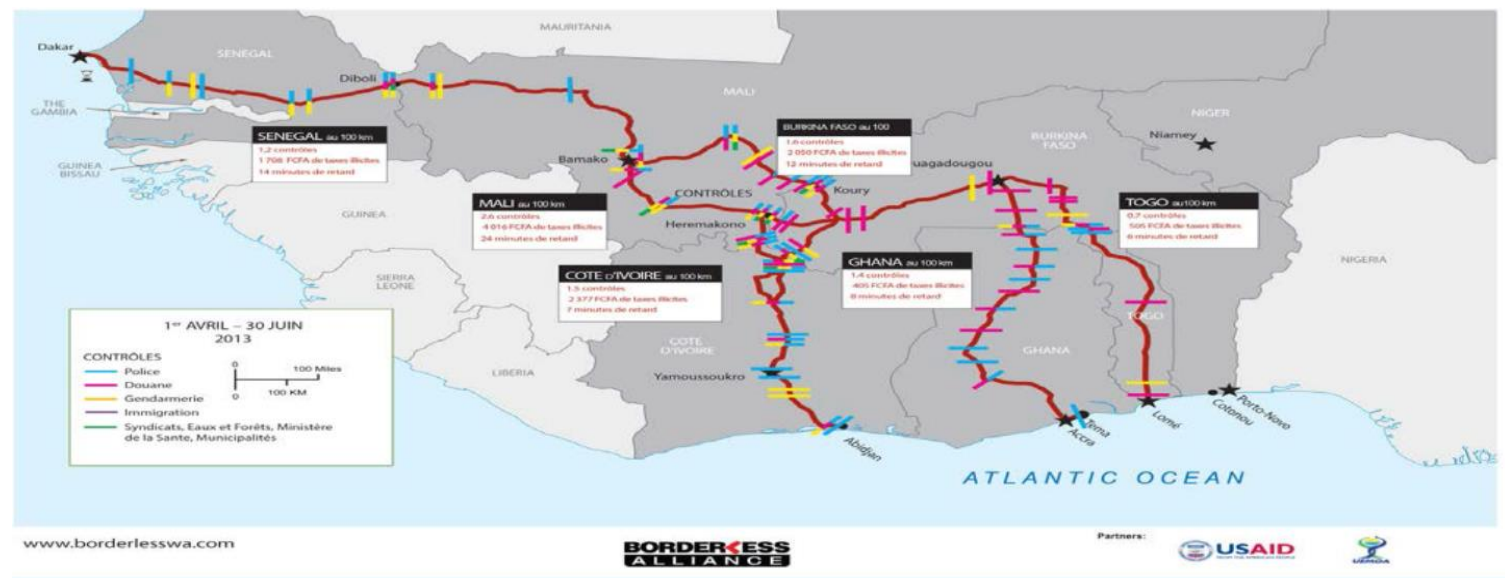

Figure 1. Road harassment on West African corridors covered by the UEMOA/USAID Trade Hub Road Governance Source: OPA, 2013

$>$ In ECOWAS, IRT is additionally, mired by the unusual costs of goods transported by highway or railway. This is all because of meagre substructure as well as the governing of the transportation sector. This predominantly affects traders within the rural areas. Transportation prices per a ton Km from the gate of the farm to the place of primary market collection has risen to be 3 to 5 times over compared to those from secondary markets to wholesale markets, which are, located in the nation's capitals (FAO and AfDB 2015.

$>$ Speedy population progression, development trends and emergent middle class, leading to enlarged demand of food and shifting consumption outlines have posed a fundamental challenge to ECOWAS countries. Besides, the Economic heterogeneity of ECOWAS is a major impediment to any meaningful trade. In addition, across border linguistic, historical, ethnic and cultural ties and differences (Note 10), unofficial trade motivated by communal based networks, which focus on collective origins, is another impediment. A number of regional institutions (e.g. ECOWAS, UEMOA and CILSS) with overlying membership and obligations complicates trade for the sub region.

$>A$ region-wide desire for policy structure to ease IRT as well as reinforce provincial value-chains like the CET, ETLS, WACIP and ECOWAP, remains high. Nevertheless, the operationalization of these schemes is difficult, thus the existence of many tariff and non-tariff barriers. Furthermore, the weak enforcement of the schemes by member states through ECOWAS complicates trade flows, such as the replication of regional policies.

\subsection{East African Community (EAC)}

The East African Community (EAC) comprises of Uganda, Burundi, South Sudan, Tanzania, Rwanda and Kenya. The core economic sector of the EAC block is agriculture, while the core catalyst to their GDP is the services sector. In effect, roughly, $80 \%$ of the populace resides in rural areas and do rely on agronomy for their survival. Between the year 2013 and 2018, the amount of intra-EAC trade in relation to the total trade reduced to roughly $10 \%$ from $13 \%$. Nations such as Uganda, Tanzania and Kenya continue to control intra-EAC trade notwithstanding the fact that its value reduced from 5.9 billion dollars to 5.6 billion dollars within the same period. Over the 2013-2018 period, Kenya's total exports to Uganda remained above 3.3 billion dollars, with Tanzania, Rwanda and Burundi at 2 billion dollars, 750 million dollars and 310 million dollars respectively. Agronomic products like wheat flour, tea, coffee, tobacco, rice, cotton and maize mainly dominate EAC trade. In addition, factory-made goods such as sugar, textiles, and cement and petroleum goods are all at the centre of these trade dealings. According to (KNBS 2016), even though, Kenya and Uganda remain the biggest economies within the region, Uganda remains a vital market for Kenyan exports. Correspondingly, Kenya imported most goods from Uganda at Ksh82 billion ( $\$ 815$ million) within the same period, (\$748.64 million) and (\$36.45 million) for Tanzania and Rwanda respectively. However, key imports did come from South Africa, totalling $\$ 3.19$ billion. Within the EAC member states economies, agriculture (Note 11) plays a foremost role, in terms of its GDP output, support means and foreign exchange incomes. The GDP input sector fluctuate from about $25 \%$ to $42 \%$ from Uganda to about Burundi respectively. 
Table 4. EAC selected trade indicators, 2011 - 2017

\begin{tabular}{|c|c|c|c|c|c|c|c|}
\hline & 2011 & 2012 & 2013 & 2014 & 2015 & 2016 & 2017 \\
\hline $\begin{array}{l}\text { Exports of goods and services (USD } \\
\text { billion) }{ }^{x}\end{array}$ & 22.1 & 25.6 & 25.3 & 26.7 & 26.7 & 25.1 & 25.1 \\
\hline $\begin{array}{l}\text { Imports of goods and services (USD } \\
\text { billion) }{ }^{x}\end{array}$ & 38.7 & 41.8 & 43.1 & 46.0 & 40.6 & 36.9 & 39.0 \\
\hline $\begin{array}{l}\text { Trade in goods and services (\%age } \\
\text { of GDP) }\end{array}$ & 57.2 & 546 & 50546 & 49599.51 & 46.2485.12 & $240.04(61)$ & 37.54807 .05 \\
\hline EAC Imports (Intra \%) ${ }^{x x}$ & 5.9 & 6.2 & 5.2 & 6.1 & 4.8 & 5.9 & 5.9 \\
\hline EAC Imports (Extra \%) ${ }^{x x}$ & 94.1 & 93.8 & 94.8 & 93.9 & 95.2 & 94.1 & 94.1 \\
\hline EAC Exports (Intra \%) ${ }^{x x}$ & 19.6 & 20.5 & 27.0 & 20.1 & 21.1 & 18.5 & 18.5 \\
\hline EAC Exports (Intra \%) ${ }^{x x}$ & 80.4 & 79.5 & 73.0 & 79.9 & 78.9 & 81.5 & 81.5 \\
\hline $\begin{array}{l}\text { Extra EAC Trade (Total Imports) } \\
\text { Africa } x x x\end{array}$ & 10.3 & 9.9 .2 & 8.38 .3 & 7.17 .1 & 6.46 .4 & 8.18 .1 & 10.410 .4 \\
\hline $\begin{array}{l}\text { Extra EAC Trade (Total Imports) } \\
\text { COMESA \& SADC }^{x x x}\end{array}$ & 9.7 & 8.9 & 7.9 & 6.9 & 6.3 & 7.7. & 10.1 \\
\hline $\begin{array}{l}\text { Extra EAC Trade (Total Exports) } \\
\text { Africa } x x x\end{array}$ & 29.9 & 30.3 & 33.1 & 35.5 & 29.8 & 28.4 & 28.4 \\
\hline $\begin{array}{l}\text { Extra EAC Trade (Total Exports) } \\
\text { COMESA \& SADC }^{x x x}\end{array}$ & 27.1 & 27.1 & 25.9 & 27.0 & 22.4 & 22.2 & 21.4 \\
\hline
\end{tabular}

1. Source $^{\mathbf{x}}$ : Member states' statistics offices; and World Bank's World Development Indicators. Viewed at: http://databank.worldbank.org/data/reports.aspx?source=world-development-indicators\#.

2. Source ${ }^{\mathbf{x x}}$ : WTO Secretariat, based on data provided by the authorities; and UNSD Comtrade

3. Source ${ }^{\mathbf{x x x}}$ : WTO Secretariat's calculations, based on data provided by the authorities; and UNSD Comtrade

The total GDP of EAC WTO Members' trading (Note 12) in goods and services is still above the $50 \%$ average. Even though intra-EAC trade in goods is trivial, however it characterizes approximately $11 \%$ of the total trade stock, which is reflected in differently in the weak infrastructure, casual cross-border trade and non-tariff barricades as well as uncontrollable managerial procedures. Consequently, with imports coming mostly from India, United Arab Emirates, China, and the European Union (Note 13), yet over 85\% of trade in goods and services for the EAC occurs externally. EAC countries, have independently agreed to pledges, usually on quite a few groups (service). Additionally, as agreed by the EAC Common Market Protocol, the members have sworn to soften certain services in, and others - tourism, commercial services across all kinds of supply, transportation, finance and interconnection (Note 14) The amount of sub-segments covered by the pledges do range between 59 and 101; Tanzania (59) and Rwanda (101).

\subsubsection{Challenges of Trade in EAC}

$>$ The EAC's unfavourable taxation regime is a major challenge to intra-regional trade. The unfavourable taxation measures in member countries further poses challenges. For example, VAT; industrial development fee and the railway development fund makes Kenya's factory-made goods 5\% more costly compared to importation from SADC and COMESA countries. Because of this situation, the exportation volume of Kenya to the EAC has suddenly dropped.

$>$ The increased business costs restrict the significance of industrialization within these economies because sectoral policies are not harmonized in the EAC. Furthermore, EAC nations do encounter several social and economic problems asides their promising agricultural conditions (Note 15). With the exception of Kenya, the other countries in EAC are all poorly developed and are yet to considerably, diversify their economies.

Key impairments towards expanding the industrialization of factory goods within the EAC includes high regulations, expensive and irregular supply of energy, import rivalry and accompanied with high business 
costs. All these therefore characterize industrialisation (Note 16) with a restricted value. EAC nations among others make available incentives for corporate income tax and the reduction of VAT and customs duties. These measures are yet to have positive impact as per IRT and have not attracted foreign investment (FI) as envisioned.

$>$ The overlying participation of economic blocks by non EAC nations particularly SADC and COMESA, are challenging and as such it additionally complicates regional trade regimes. Even though, in June 2015, dialogs were achieved for a three-way (COMESA-SADC-EAC) Free Trade Agreement (FTA) in goods and services along with an assessment to restructuring integration methods within the area, the desirable results are still to be seen. Trade exchange services as well as other related trade areas (together with intelligent property rights, policy struggle) are still on going and there is no evidence of a counterfactual analysis on how these discussions will affect AfCFTA.

$>$ Notwithstanding high-level commitments by member nations, trade complications continue to distraught the unrestricted movement of goods and services among EAC states. Even if trade tariffs have been discarded amongst members, yet, non-tariff barriers (NTBs) (Note 17) remain common and do comprise a main obstacle. Additionally, NTBs and twofold taxation for companies that are functioning within two or more member countries are amongst weighty challenging complications, which industries within the EAC region face.

\subsection{Southern African Development Community (SADC)}

The Windhoek Treaty of 1992 within the Southern African Development Community (SADC) setting defined the main aim of the regional block as economic. This was in contrast to its predecessor ((Evans 1997a.). SADC comprises of fourteen member nations namely Angola, DRC, Malawi, Namibia, Swaziland, Zambia, Lesotho, Mauritius, Botswana, Mozambique, Seychelles, South Africa, Tanzania and Zimbabwe. The SADC region comprises of divergent economies in terms of output structure and economic size as well as performance (Evans 1997b.) and (Holden 1996). For instance, the economy in South African is 4 times more than the total GDP of all the other SADC nations combined with a GDP per capita that is 7 times bigger than the average SADC per income capita. Most of the SADC states' structure of production is focused on primary goods while Swaziland, Namibia, Zimbabwe and Mauritius remains alike to that of South Africa. Correspondingly, the industrial segments for majority of these nations are mainly small. While Zambia and Zimbabwe's industrial segments are somewhat progressive, they are yet not near to South Africa's expanded industrial base. Evans (1998) emphasizes that these incongruences do rise from a mixture of fundamental economic bequests, the scope of involvement in the intercontinental labour division, the official context and expertise.

Nevertheless, both intra African trade and without a doubt intra SADC trade, have remained somewhat low notwithstanding the swing. In a wide-ranging setting, exports from SADC constitute about $16 \%$ of the total African continent and a meagre $4 \%$ in worldwide exportation. In contrast, SADC imports constitute on average, about $15 \%$ of the entire import from within the continent of African and 4\% of worldwide imports. However, in relation to trade, Zimbabweans and South Africans remain the main figure-actors in the region and their exports constitute more than $90 \%$ of total regional exports. With these disproportions in the region amidst universal setting, it is apparent that added liberalization and harmonization of trade strategies would not be advantageous to the smaller SADC nations except communal evolutional schedules are adopted. These schedules, though, would necessitate the documentation of up-and-coming expanses that could be exploited by the much smaller nations.

In the last few years, the improvement of IRT within the SADC region has garnered attention and substantial emphasis have been placed on the integration process. In order to progress intra-SADC trade, a number of thoughtful policies as well as authorized requirements have been executed. Up until now, there is no remarkable growth in IRT in Southern Africa. Ever since the 2008 (SADCFTA 2008) and ((Mayer and Thomas 1997) )free trade area (FTA) formation, intra-SADC trade has somewhat increased to $10 \%$; however this is low when comparing it to other regions like European Union (40\%) and the South-East Asian Nations (24\%). Statistics indicates that about $90 \%$ of trade in the SADC region is mostly with outside countries. 
Table 5. SADC country merchandise and share to members

\begin{tabular}{|c|c|c|c|c|}
\hline $\mathbf{S} / \mathbf{N}$ & Countries & $\begin{array}{l}\text { Total } \\
\$ \mathrm{~m}\end{array}$ & Exports & Share to SADC\% \\
\hline 1. & Botswana & 5149 & & 6 \\
\hline 2. & Madagascar & 2140 & & 3 \\
\hline 3. & Malawi & 1536 & & 21 \\
\hline 4. & Mauritius & 3278 & & 13 \\
\hline 5. & Mozambique & 3661 & & 23 \\
\hline 6. & Namibia & 4689 & & 17 \\
\hline 7. & South Africa & 93550 & & 11 \\
\hline 8. & Tanzania & 4106 & & 6 \\
\hline 9. & Zambia & 11324 & & 8 \\
\hline 10. & Zimbabwe & 2154 & & 31 \\
\hline 11. & Angola/DRC & 46392 & & 6 \\
\hline 12. & $\begin{array}{l}\text { Lesotho/ } \\
\text { Swaziland }\end{array}$ & 2066 & & 7 \\
\hline
\end{tabular}

Source: GTAP database V9.1. Trade data for 2011. Excludes Seychelles

Amongst members of the SADC region, there exists very limited trade; however, this is all because the trade shares among members is low. Nevertheless, initial trade low levels might suggest that decreasing non-tariff measures (NTM) would have a small trade effect, principally if the ad valorem NTMs equality is in order of $10 \%$ to $20 \%$. Excluding Angola, Democratic Republic of the Congo and the Zimbabwe, tariffs from the SADC region have been virtually removed. From South Africa, Zimbabwe alone obtained a $16 \%$ average on tariff s from importation. Despite all these reliefs, IRT trade share has since not grown in part even as tariff have dropped. At present, the tariffs are about $10 \%$.

\subsubsection{Challenges of SADC Trade}

$>$ The arrangement of trade suggests that for most of the SADC countries, there is a restricted space to progress into the manufacturing of extremely good quality merchandises, even if they desire to diversify their exports. Export supply capabilities limitations are prohibiting the smaller countries from exploiting possible niche markets. Thus, the inability of the smaller countries to generate foreign currency required to increase trade because of lack of economies of scale.

$>$ South Africa controls a substantial trade excess for the region and plays a leading role in the region, but its exports into the region overshadow its imports from the region. Furthermore, it's manufacturing value added (MVA) is five times larger than that of MVA total from added member nations, and also 15 times the Zimbabwean MVA which is the $2^{\text {nd }}$ biggest manufacturer in the SADC region.

$>$ Intra-SADC trade is not developing swiftly because of both tariff and non-tariff obstacles and ineffectual implementation of trade responsibilities (Mayer and Thomas 1997).

> Correspondingly, this zone encompasses many LDCs without exceptional rations for such nations. Operationally, the SADC code of conduct truly does corrodes some of the advancements made during Round of GATT in Uruguay (1994) (Note 18). Thus, the sustainability of trade flows even within the AfCFTA framework is questionable.

\section{Discussion}

The main home to African continent's one-third populace is West Africa. The difficulty of food security is predominantly dire in this area, with part of the world's largest rising populaces and fast suburbanization tendencies, meteorological susceptibility, conflicting and party-political unpredictability, to name a few. Despite long-lasting and sturdy assurances towards "the removal of hurdles to the free movement of persons, goods, service and capital", as 
enshrined in the ECOWAS Pact, there exists several trade barriers. Another challenge, (Note 19) which is major for AfCFTA, is the overlap between two economic blocks COMESA and SADC. Nevertheless, COMESA's locus is weakened by the fact that South Africa is not a group-member as an extensively thought opinion that its resolution not to work with COMESA has 'frustrated its schedule' and 'reduced its standing in the region. In September 1995, during a SADC conference, an understanding was reached that associates of both COMESA and SADC were inharmonious, and consequently SADC states had to pull out from COMESA. These actions do highpoint rigidities amongst the two groups, even though evidently, members of SADC have not completely pulled out from COMESA. This ambiguity must be resolved for trade benefits between the member states.

To accomplish a vibrant and robust trade structure within African, the efficient implementation of complementary strategic continental initiatives, such as the Comprehensive Africa Agriculture Development Programme, the Programme for Infrastructure Development in Africa of the New Partnership for Africa's Development, the action plan of the Accelerated Industrial Development for Africa initiative of the African Union and the Action Plan for Boosting Intra-African Trade of the African Union. Constancy in vision, along with the timely implementation of various continental programmes, such as those cited, is key to ensuring that regional integration delivers on its objectives. Thus, regional integration that exclusively highlights the removal of tariff and non-tariff barriers, on its own, cannot deliver on the stated goals of promoting development for the continent. Regional integration should be complemented by the building of capacities that are productive, structural transformation acceleration and the releasing of the private sector potential.

A more open continent will shape reliability for Africa's in the eyes of the world, which will positively, reward it with more access to outside markets. However, enhancing intra-regional trade is more than eradicating tariffs, but rather focuses on attending to pressing constrictions, which paralyze the daily trade actions. Effective region-wide trade integration can support African nations to secure economies of scale, enlarge marketplaces and jointly exploit their resources, thus, slowly but surely rising their competitiveness within the international economy. Furthermore, regional integration can decrease countries dependency on routine trade and increase their elasticity countering negative externalities. The foremost impediment fronting the African continent is non-developed nature of most of the countries on one-hand and trade supply constraints that most of these countries are suffering from. Even though sluggishly growing, trade within African is low. In 2017 the total African continental exportation and importation from the entire continent was less than $20 \%$. For these circumstances, there are many whys and wherefores: the African economic dependency on product manufacture and exportation, non-tariff and tariffs barriers (NTBs (Note 20)), disorganized transportation substructure, high protection risks and weak trade logistics. Further, challenges such as a smaller amount of diversity in trade leading to a misalliance between demand and supply, corresponding memberships, heterogeneity of the economies, loss of import-export tax revenue, absence of pragmatic political leadership, loss of national sovereignty in most cases, weak private sector involvement, and deplorable infrastructure are pervasive across the regional blocks. Additionally, bad policies and poor regulatory environment frequently compound challenges already existing within sub-Saharan Africa. Sub-structural, technical and policy restraints produce trade holdups, multipart authorization processes, unwieldly certification requirements and impulsive trade policies add to the rising costs of trade within the African continent. Such limitations do arise from ill-industrialized economic marketplaces. In-addition, the non-existence of across border economic policies, multifaceted measures operating private-owned corporations, complex custom measures, and restricted region-wide synchronization of policies, rules, and measures amongst many others portends a huge obstacle for the actualization of AfCFTA.

\section{Summary}

In recognition of the importance of the necessity to broaden the horizons of Africa's economy as well as boost its creative capability, Governments and Heads of State have implemented several reforms. The greater operationalization test of the AfCFTA situates the involvement of all the countries and in-addition, there is a similar problem on how larger economies like Nigeria, South Africa, Kenya and Egypt, will profit from this pact, and how others will be sheltered from them. Intra-African trade presents positive breaks for persistent development in Africa only if the structural and supply-side limitations are resolved by member states for easy of regional integration. Consequently, seizing these prospects entails that the dynamism of the private sector must become accessible with a developmentally based approach towards integration. From an economic standpoint, the scope of the established regional institutions must be rearranged to profit member countries. Each of the blocks should benefit from the overflow from another block.

Nevertheless, outside the difficulties of infrastructure, lack of financial access, political ambiguity, inter-region-wide restraints on unrestricted mobility and the increasing demand for western goods by African consumers, AfCFTA still 
portends to be a solution. AfCFTA offers substantial benefits for the continent, as it could lead to a stronger integration among countries. Achieving victory in advancing trade within the African continent hinges on mainly on the degree to which African nations have the capacity to nurture free enterprise and form supply capability, which should be the framework of any policy agenda. The establishment of a trustworthy machinery for exchange of ideas among businesses and the State and building region-wide chain value are imperative to boosting intra-African trade. Thus, the prospect of realizing the purposes of AfCFTA adding to the construction of a superior and unified marketplace for African goods becomes probable. Furthermore, the treaty's implementation does require a thoughtful, conviction, and assurance of the private segment. Predominantly, a dynamic participation of this segment and the community at large would be fundamental to the AfCFTA pact. Trade acceleration can support the broadening of market integration in Africa and the optimal performance of African countries in the international trade, and particularly AfCFTA. However, a fundamental concern in the low level of intra-African trade that will inhibit the operations of AfCFTA are the numerous trade facilitation constraints. Larger political commitment to regional integration as indicated in fuller application of tariff liberalization schedules and concerted efforts to tackle non-tariff barriers. Also, longer-term policies to address export supply capability constraints at the national level are desperately needed. Hence, the elimination of these limitations is an absolute to enhancing trade among African countries as per the vision of AfCFTA. Consequently, if these limitations are not eradicated, the elimination of tariffs on intra-African trade that has been the major emphasis of regional market integration efforts will have limited effect in enhancing these trades.

\subsection{Policy Recommendations}

This article contributes to the on-going debate about the benefits of the recently launched African Continental Free Trade Area (AfCFTA). It points out the obstacles that must be addressed across the continent for the objectives to be realized. Nevertheless, liberalization of trade is essential for economic development; conversely, it is not a sufficient condition. To achieve the goals of AfCFTA, the article recommends the following:

a) Member nations must streamline the many obscurities currently inherent in the AfCFTA. This can be achieved by fashioning a roadmap of the remaining unknowns: for instance, who is discussing what with whom or what will happen to customs unions if not all members have endorsed the pact, in addition to how conflicts will be resolved. Further, greater political commitment to regional integration is also vital and long-term strategies to tackle export-supply ability restraints is imperative. Institutional frameworks in member states must be strengthened to achieve its objectives. Member states must be held accountable for non-acquiescence. It is therefore imperative to improve inner funding structures that are unwavering to supporting the region-wide trade- linked missions.

b) Services are fundamental to intra-regional trade for the reason that they are job generating and production-augmentation. Therefore, inputs into the competitive advantage of nearly other several events are of specific significance in letting businesses to partake in region-wide and international value chains'. AfCFTA modus operandi should add extra services not enclosed by existing procedures. Therefore, the furthering of trade within African necessitates that strategic African continental trade is to be planned in such a manner that no other country in Africa can obtain a less positive dealing than that which is given to others, regardless developmental state of the country.

c) At the moment, cargo costs for importation to non-coastal African countries are two times as high as in Asia. In a bid to encourage trade mobility regionally, expansion of infrastructural investment such as railways, roads, air power lines facilities and communications are mandatory. For AfCFTA to produce gains, member nations most also overcome the trade supply limitations. The globe is shifting in terms of economic arrangement, forms of trade, power and the predominant economic convention. Consequently, it is vital that countries in Africa also adjust their approach to integration and regional trade. This means an adaptation to the swiftly changing world. In this context, an all-inclusive and coherent style to integration is needed to improve intra-African trade and regional integration on the continent.

d) Many of the Non-Tariff Measures (NTMs) in Africa are technical, practical and challenging to swap. Nonetheless, NTMs must be used in a transparent and non-discriminatory style. By means of a set of international principles, , possibly will be helpful, rather than national standards. Further, to realizing the framework for AfCFTA, some Technical Barriers to Trade (TBTs) across all regional blocks must be removed but in order to safeguard consumers and the environs, caution should be applied on some of the items. Again, international standards should be used to the extent possible. 
e) Polarisation of development is already evident in Africa. The more advanced countries gain from FTAs while the LDCs struggle. Solving this issue requires, a disproportionate operation of the FTA amongst African states. Principally, South Africa, Nigeria, Egypt and Kenya must have an understanding with the rest of African states with respect to scheduling and product lines. This is so because the above-named countries will liberalize faster and accept more product lines than the other states. This leads to a discussion on the rules of origin and how it should be used for comparable gains within the AfCFTA framework. Besides, the South African economy is not large enough to serve as a growth pole for the continent. Efforts should be made to smoothen access to EU markets in concert with Nigeria, Egypt and Kenya as leading economies of the continent. This will provides substantially bigger gains for AfCFTA in the long run.

f) Re-building intra-African trade would encourage specialty amongst African countries. This would improve diversification and competitiveness by building regional value chains. African countries therefore need to chase aggressively, all-inclusive and harmonized regional trade policies as a strategy for regional integration.

\section{Acknowledgments}

The author wishes to thank anonymous reviewers that made useful contributions to the Manuscript.

\section{Conflict of Interest}

There is NO CONFLICT OF INTEREST. The views expressed in this article are mine, and not the official position of the University of Mpumalanga.

\section{References}

African Centre for Trade, Integration and Development. (2012). The reality of trade in West Africa. Annual Report.

African Development Bank. (2011). Integration for Africa's Economic Prosperity. Retrieved from https://www.afdb.org/fileadmin/uploads/afdb/Documents/Publications/2019AEO/AEO_2019-EN-CHAP3.pdf

African Development Bank. (2011). Regional Integration Strategy Paper for West Africa 2011-2015. Tunis: African Development Bank.

African Export-Import Bank (Afreximbank). (2018). Africa Trade Report. Cairo: Afreximbank, p. 15. PricewaterhouseCoopers.

Alemayehu, G., \& Haile, K. (2007). Regional Economic Integration in Africa: A Review of Problems and Prospects with a Case Study of COMESA. Journal of African Economies, 17(3), 357-394.

Cuts International. (2015). From COMESA to TFTA. Integrating the Voice of the Civil Society in Ethiopia. Nairobi.

Economic Commission for Africa. (2015). Intra-African trade and Africa Regional Integration Index: Progress report on intra-African trade. $\quad$ Retrieved from https://www.tralac.org/images/docs/8506/intra-African-trade-and-africa-regional-integration-index-progress-rep ort-uneca-september-2015.pdf

Engel, J., \& Jouanjean, M. A. (2013). Barriers to trade in food staples in West Africa: An Analytical Review. London: ODI.

Evans, D. (1997a). Technical appendix, From Study of the Impact of the Removal of Tariffs for the Free Trade Area of the Southern African Development Community (SADC). Report prepared for the SADC Industry and Trade Coordination Division SITCD, Institute of Development Studies, University of Sussex.

Evans, D. (1997b). The Uruguay Round and the Free Trade Area of the Southern African Development Community (SADC), Draft. Mimeo, Institute of Development Studies, University of Sussex, June.

Evans, D. (1998). Options for Regional Integration in Southern Africa. Paper presented at the Trade and Industrial Policy Secretariat Forum, September, Johannesburg.

FAO, African Development Bank. (2015). Agricultural Growth in West Africa: Market and Policy Drivers. Rome: FAO/AfDB.

Holden, M. (1996). Economic integration and trade liberalisation in southern Africa: is there a role for South Africa. World Bank Discussion Paper No. 342, World Bank, Washington D.C.

Hulse, M. (2014). Actorness beyond the European Union: Comparing the International Trade Actorness of SADC and ECOWAS. Journal of Common Market Studies, 52(3), 547-565. 
International Trade Centre (ITC). (2012). Africa's Trade Potential: Export Opportunities in Growth Markets, Geneva: ITC, 2012. xi, 43 pages (Technical paper) Doc. No. MAR-12-226.

Jibrilla, A. (2018) African Continental Free Trade Area (CFTA) and its Implications for Nigeria: A Policy Perspective. International Journal of Research and Innovation in Social Science, 2(12), 164-174.

Kenya's Economic Survey. (2016). Kenya National Bureau of Statistics (KNBS). Survey Publication Report Marinov, Eduard (2014) Economic Integration Theories and the Developing Countries. In Dautov, R., Gkasis, P., Karamanos, A., Lagkas, T., Prodromidou, A., \& Ypsilanti, A. (Eds.), Infusing Research and Knowledge in South-east Europe (pp. 164-177). Thessaloniki: South-East European Research Centre.

Mayer, M. J., \& Thomas, R. H. (1997). Trade Integration in the Southern African Development Community: Prospects and Problems. Development Southern Africa, 14(3), 330-331.

Mushonga, M., \& Ikhide, S. (2017). An Evaluation of the Effectiveness of Trade Protocol on Non-Tariff Barriers to Trade in the SADC Free Trade Area. In Hartzenberg, T., \& Erasmus, G. (Eds.), Monitoring Regional Integration: 2017, Yearbook 2015/2016. Tralac: Stellenbosch.

OECD. (2019). Informal Cross-Border Trade and Trade Facilitation Reform in Sub-Saharan Africa. Paris: OECD.

PricewaterhouseCoopers. (2019). AfCFTA Thriving in a New Africa. Retrieved 8 July 2019, from www.pwc.com/ng

SADC FTA. (2008). Retrieved from http://www.sadc.int/about-sadc/integration-milestones/free-trade-area

Stiglitz, J. (2002). Globalization and its Discontents. London: Penguin.

Ubi, E. (2018). Nigeria's Abstention from the CFTA Agreement was No Mistake. Retrieved 18 July 2019, from http://www.financialnigeria.com/nigeria-sabstention-from-the- cfta-agreement-was-no-mistake-blog347.htm

UNCTAD. (2013). Economic Development in Africa Report: Intra-African Trade -Unlocking Private Sector Dynamism. United Nations publication. Sales No. E.13. II.D.2. New York and Geneva.

UNCTAD. (2015). Economic Development in Africa: Rethinking the Role of Foreign Direct Investment. Geneva.

UNECA. (2019). The Continental Free Trade Area (CFTA) in Africa - A Human Rights Perspective. Geneva: Friedrich Ebert Stiftung.

Viljoen, W. (2011). The intra-Africa non-tariff barrier dilemma: the challenges facing the AfCFTA approach. Tralac: Trade Law Centre; AfDB, 2019. Retrieved from http://www.tralac.org

Wandrei, K. (2018). Advantages and Disadvantages of Regional Integration. Retrieved 18 July 2019, from https://classroom.synonym.com/advantagesdisadvantages-of-regional-integration-12083667.html

World Bank. Connecting Food Staples and Inputs Markets in West Africa - A Regional Trade Agenda for ECOWAS countries; 2015 Washington DC, World Bank Group.

Yusuff, S. O. (2014). Gender dimensions of informal cross border trade in West-African sub-region (ECOWAS) borders. International Letters of Social and Humanistic Sciences, 19-33.

\section{Notes}

Note 1. The economy of several African states is reliant on the production and export of primary commodities.

Note 2. African states can trade more with each other if they can step-up their productive capacities in the productive dynamic sectors and encourage the development of regional enterprises and value chains.

Note 3. The only other region with a higher export dependence on the rest of the world is Oceania.

Note 4. The insignificant role of the private sector in regional integration initiatives and efforts has also contributed to the negligible trade performance of the continent.

Note 5. Women in Africa currently manage $70 \%$ of informal cross-border trade, which is a huge figure and indicates the involvement of Women in trade facilitation in Africa.

Note 6. The potential to generate employment, expand investment and nurture growth in Africa via Intra-African trade is huge.

Note 7. Besides, the output of most of the productive sectors in particular, the manufacturing industry (which is characterized by high tariff and import penetration) would probably decline due to the inflow of cheap imports in the local market 
Note 8. West Africa has huge potential for trade both in global and intra-regional terms. Nevertheless, trade has substantial probability to increase, in step with ECOWAS ambitions.

Note 9. Besides, borders often separate production areas from the nearest market.

Note 10. Anglophone versus Francophone members of ECOWAS

Note 11. Products are coffee, cut flowers, tea, tobacco, fish and vegetables dominate agricultural exports. A main agriculture policy urgency is to attain food security.

Note 12. Including intra-EAC trade

Note 13. These locations are also amongst the foremost export markets.

Note 14. Countries are also committed to refraining from introducing any new restrictions on the provision of services.

Note 15. Their important sources of renewable energy, and their total population of over 168.2 million.

Note 16. Manufacturing is highly concentrated in agro-processing activities, and is dominated by micro, small and medium enterprises.

Note 17. These refers to restrictions, unrelated to tariffs, that result from quotas, import licensing systems, prohibitions, regulations, conditions or specific market requirements that make the importation or exportation of products difficult and/ or costly

Note 18. During this round, tariffs on agricultural goods, export subsidies, standards with respect to technical regulations, textiles and clothing and the elimination of tariffs were discussed.

Note 19. South Africa was invited to join COMESA in May 1994, but refused.

Note 20. NTBs are major obstacles to intra-Africa trade.

\section{Copyrights}

Copyright for this article is retained by the author(s), with first publication rights granted to the journal.

This is an open-access article distributed under the terms and conditions of the Creative Commons Attribution license (http://creativecommons.org/licenses/by/4.0/). 